Jurnal Intelektualita: Keislaman, Sosial, dan Sains

Vol. 10 No. 2 (2021)

DOI: https://doi.org/10.19109/intelektualita.v10i2.8909

Copyright (C) 2021 Sidra Muntaha Irawan, Dinnul Alfian Akbar, Rinol Sumantri

\title{
Analisis Pengaruh Financial Literacy, Asymmetry Information terhadap Keputusan Investasi di Pasar Modal Syariah dengan Investasi Etis Sebagai Variabel Intervening
}

\author{
Sidra Muntaha Irawan ${ }^{1 *}$, Dinnul Alfian Akbar, Rinol Sumantri \\ ${ }^{1}$ UIN Raden Fatah Palembang, Indonesia
}

\begin{abstract}
Abstrak: Penelitian ini bertujuan untuk mengetahui seberapa besar pengaruh financial literacy, asymmetry information dan investasi etis dalam mengambil keputusan investasi bagi para investor individu di Kota Palembang pada tahun 2020. Penelitian ini bersifat kausal menggunakan data primer 70 responden dengan teknik purposive sampling. Data hasil penelitian dianalisis dengan menggunakan metode Structural Equation Modeling (SEM) berbasis Partial Least Square (PLS). Penelitian ini menyimpulkan bahwa financial literacy berpengaruh terhadap investasi etis, asymmetry information berpengaruh terhadap investasi etis, financial literacy tidak berpengaruh terhadap keputusan investasi, asymmetry information berpengaruh terhadap keputusan investasi, investasi etis berpengaruh terhadap keputusan investasi, dan investasi etis berpengaruh memediasi antara financial literacy terhadap keputusan investasi dan asymmetry information terhadap keputusan investasi.
\end{abstract}

Kata Kunci: financial literacy, asymmetry information, investasi etis, investasi, saham

\begin{abstract}
This study aims to figure out how much the influence of financial literacy, asymmetry information, and ethical investment on investment decision making of individual investor in Palembang in 2020. This causal study used primary data of 70 respondents with purposive sampling technique. The research data were analyzed using the Structural Equation Modeling (SEM) method based on Partial Least Square (PLS). The results of the analysis show that (1) financial literacy affects ethical investment, (2) asymmetry information affects ethical investment, (3) financial literacy does not affect investment decisions, (4) asymmetry information affects investment decisions, (5) ethical investment affects investment decisions, and (6) ethical investment mediates financial literacy on investment decisions, and asymmetry information on investment decisions.
\end{abstract}

Keywords: financial literacy, asymmetry information, ethical investment, investation, stock

\section{Pendahuluan}

Pertumbuhan ekonomi Islam di Indonesia dewasa ini sangat signifikan dengan munculnya berbagai institusi keuangan yang berorientasikan pada kuntungan maupun yang bertujuan untuk sosial (Huda, 2015), pemerintah Indonesia telah menyediakan beberapa instrumen keuangan berbasis ekonomi Islam yang saat ini telah berkembang menjadi suatu aliran ekonomi di dunia salah satunya adalah pasar modal. Pasar modal memiliki peran untuk menjalankan dua fungsi utama yaitu merupakan sarana untuk pendanaan usaha bagi perusahaan dan fungsi kedua sebagai

\footnotetext{
* Corresponding Author: Sidra Muntaha Irawan (sidramuntahairawan03@gmail.com). UIN Raden Fatah Palembang, Indonesia
} 
alat atau sarana yang dapat digunakan investor untuk menginvestasikan uangnya pada berbagai instrument investasi yang ada di pasar modal seperti saham, obligasi dan reksadana (Umam, 2013). pengakomodasian keuangan dengan prinsip Islam adalah wujud andil pemerintah dan masyarakat dalam membangun kegiatan perekonomian melalui investasi syariah di pasar modal untuk berkontribusi dalam pembangunan nasional (Zulfikar, 2017).

Investasi atau penanaman modal adalah suatu kegiatan yang sangat penting bagi suatu perekonomian organisasi maupun perorangan (Pradhana, 2018). Berinvestasi di pasar modal selain mendapatkan keuntungan investor harus waspada terhadap risiko yang ada di dalam aktivitas pasar modal yang diakibatkan dari perubahan mekanisme pasar dan ekonomi local serta siklus ekonomi internasional. Pola dari risiko sama dengan ketidakpastian (uncertainty) akan terjadinya suatu kejadian yang menimbulkan masalah dan peluang bagi perusahaan, pemerintah dan perorangan dalam kehidupan sehari-hari, sehingga mempengaruhi tingkat pengembalian (expected rate of return) sebagai harapan investor dari investasi di pasar modal (Umam, 2013).

Perkembangan investasi di pasar modal syariah meningkatkan cukup signifikan dari tahun 2017 sampai dengan 2020, terlihat dari jumlah investor yang meningkat dari akhir tahun 2017 sebesar 1.025.414 menjadi 1.695.268 pada akhir tahun 2020, khusunya pada kota Palembang terjadi peningkatan yang cukup signifikan pertumbuhan investor pada tahun 2017 jumlah Self ID di kota Palembang sebesar 7.706 menjadi 21.392 pada tahun 2020 (Mulyono, 2021) seperti yang digambarkan pada grafik pertumbuhan investor dibawah ini.
Grafik 1. Pertumbuhan Investor di Kota Palembang

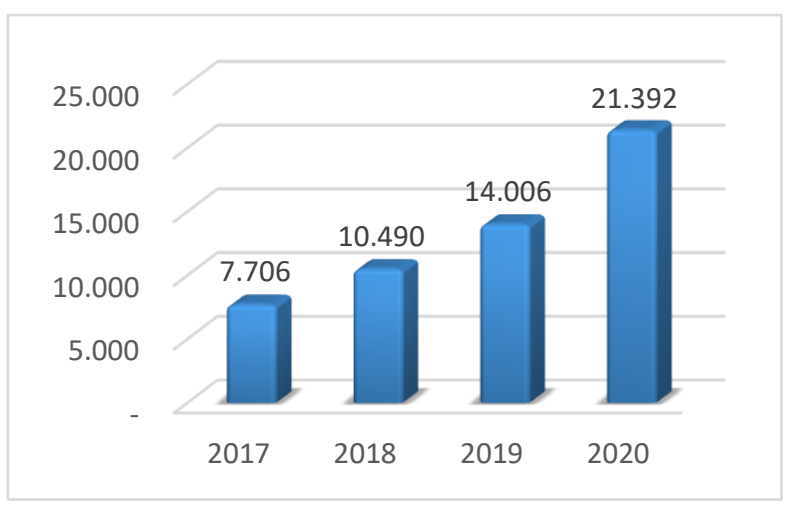

Sumber: Bursa Efek Indonesia, 2020.

Tingginya minat masyarakat kota Palembang pada investasi di pasar modal menjadi sinyal positif bahwa masyarakat kota Palembang sudah semakin inovatif dalam pengembangan asset dan pemanfaatan instrumen investasi yang telah disediakan oleh pemerintah. Meningkatnya jumlah investor dan aktivitas perdagangann yang tinggi, akan mempengaruhi investor dalam menentukan keputusan investasi, investor akan dihadapkan oleh berbagai macam keadaan dan situasi yang dapat memepengaruhi strategi dan keputusan investasi.

Secara umum tingkat risiko pada investasi di pasar modal dipengaruhi oleh kondisi perekonomian negara tersebut khususnya bidang politik, arah kebijakan ekonomi dan kebudayaan sosial setempat dan juga kondisi dalam perusahaan ang bedampak pada keuntungan (capital gain) atau risiko kerugian (capital lost) harga saham perusahaan tersebut, kerena itu investasi yang baik akan dapat memberikan dampak terhadap pertumbuhan ekonomi dan meningkatkan pendapatan perusahaanya (Hidayat, 2018).

Saham syariah menjadi salah satu pilihan bagi investor pasar modal dalam melakukakn investasi, saham syariah merupakan sertifikat/surat kepemilikan dari perusahan-perusahaan yang memiliki karakteristik sesuai dengan syariat Islam 
baik itu dari kegiatan usaha maupun pengelolaanya (MUI, 2012), proses penerepan prinsip syariah di pasar modal Indonesia mempunyai kepastian hukum di bawah otoritas jasa keuangan (OJK), OJK mengonversi prinsip-prisip syariah di pasar modal Indonesia ke dalam peraturan OJK No.15/POJK.04/2015 tentang penerapan prinsip syariah di pasar modal (OJK, 2015).

Perkembangan saham syariah di Indonesia mengalami peningkatan yang cukup signifikan baik itu dari segi penambahan jumlah emiten dan kapitalisasi pasar saham syariah. Sepereti yang digambarkan pada grafik. 2 di bawah ini:

Grafik 2. Perkembangan Kapitalisasi dan Emiten Saham Syariah

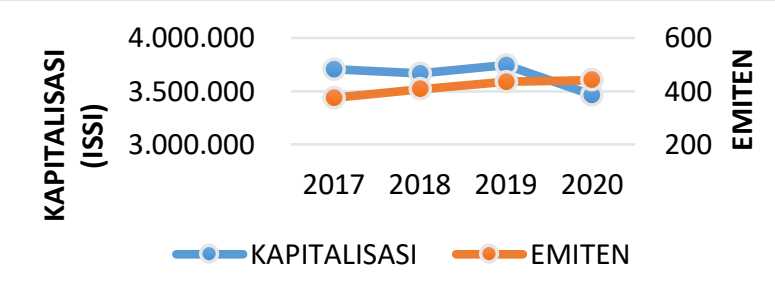

Grafik 2 menggambarkan kapitalisasi pada ISSI dan jumlah emiten saham syariah selalu mengalami perkembangan meskipun pada tahun 2020 kapitalisasi saham syariah sedikit mengalami penurunan, namun berbanding terbalik dengan pertumbuhan emiten saham mulai tahun 2017 selalu mengalami peningkatan hingga tahun 2020. Kapitalisasi saham syariah memang belum dapat menyaingi kapitalisasi pasar LQ45 hal ini menunjukan bahwa meskipun emiten saham syariah terus mengalami pertumbuhan tapi tidak dengan minat investor untuk memperdagangkan emiten-emiten tersebut. Hal ini menjadi pertanyaan apa yang menjadi penyebab saham syariah tidak terlalu diminati untuk diperdagangkan, Kahneman dan Tvesky. A (1979) mengembangkan prospect theory adalah teori yang dikembangkan yang menggabungkan 2 (dua) disiplin yang berbeda yaitu ekonomi dan psikologi (emosi) yang mempengaruhi penilaian dan pengambilan keputusan investor (Kahneman, 1979).

Investasi pada hakikatnya merupakan penempatan sejumlah dana pada saat ini dengan harapan untuk memperoleh keuntungan di masa mendatang (Halim, 2005). Beberapa investor memiliki alasan yang beragam dalam melakukan investasi, tergantung dari individu masing-masing dan dipengaruhi oleh banyak faktor (Tandelili, 2010). Seorang individu yang memiliki untuk berinvestasi harus memikirkan berbagai macam aspek dan risiko yang harus dipertimbangkan dalam mengambil keputusan untuk berinvestasi, profil risiko dari masing-masing individu memiliki perbedaan sesuai dengan financial literacy, risk aversion dan informasi yang diterima (Hunjra, 2016).

Keputusan investasi investor dipengaruhi oleh berbagai macam factor, salah satunya financial literacy (literasi keuangan), financial literacy adalah kemampuan atau pengetahuan terkait keuangan yang dapat diproses dan digunakan sebagai dasar tindakan selanjutnya (Skagerlund, 2018). Asymmetry Information adalah ketidakpastian dan keseimbangan informasi yang diterima, adanya asymmetry information memungkinkan konflik yang terjadi antara principal dana gen untuk saling mencoba memanfaatkan pihak lain untuk kepentingan sendiri. Dalam penyajian informasi akuntansi, khususnya penyusunan laporan keuangan, agen juga memiliki informasi yang tidak seimbang sehingga dapat lebih fleksibel mempengaruhi pelaporan keuangan untuk memaksimalkan kepentinganya (Made, 2018). Terdapat beberapa faktor-faktor yang mempengaruhi keputusan investasi investor. 


\section{Metode Penelitian}

Metode analisis yang digunakan dalam penelitian ini yaitu analisis jalur (path analysis). Metode analisis ini dapat digunakan untuk mengetahui besarnya pengaruh hubungan financial literacy, asymmetry information terhadap keputusan investasi di pasar modal syariah dengan investasi etis sebagai variabel intervening. Data yang digunakan dalam penelitian ini adalah data primer dengan teknik pengumpulan data dilakukan dengan penyebaran kuesioner. Populasi penelitian adalah investor di kota Palembang yang sesuai kriteria untuk dijadikan responden. Jumlah sampel dalam penelitian ini adalah 70 responden, Penelitian ini menggunakan teknik purposive sampling. Pada penelitin ini analisis data yang digunakan adalah uji validitas, uji reliailitas dan uji hipotesis dengan SEM (structural Equation Modeling).

\section{Hasil dan Pembahasan}

\section{Pengujian Model Pengukuran (Measurement Model)}

\section{a. Outer Loading Factor}

Nilai loading factor sebesar 0,50 atau lebih dianggap memiliki validasi yang cukup kuat untuk menjelaskan konstruk laten. Nilai outer loading awal pada variabel religiusitas, fundraising, minat berwakaf dan kesadaran dapat dilihat pada Tabel berikut Menurut Yamin dan Kurniawan indikator yang memiliki nilai loading factor antara 0.5 -0.6 dapat diterima.

Tabel 1. Outer Loading

\begin{tabular}{|c|c|c|c|c|}
\hline & $\begin{array}{c}\text { Asymmetry } \\
\text { Information }\end{array}$ & $\begin{array}{c}\text { Financial } \\
\text { Literacy }\end{array}$ & $\begin{array}{c}\text { Investasi } \\
\text { Etis }\end{array}$ & $\begin{array}{c}\text { Keputusan } \\
\text { Investasi }\end{array}$ \\
\hline FL1 & & 0.955 & & \\
\hline FL2 & & 0.971 & & \\
\hline FL3 & & 0.897 & & \\
\hline AI1 & 0.977 & & & \\
\hline
\end{tabular}

\begin{tabular}{|l|l|l|l|l|}
\hline AI2 & 0.969 & & & \\
\hline AI3 & 0.941 & & & \\
\hline KI1 & & & & 0.927 \\
\hline KI2 & & & & 0.962 \\
\hline KI3 & & & & 0.948 \\
\hline KI4 & & & & 0.763 \\
\hline IE1 & & & 0.867 & \\
\hline IE2 & & & 0.937 & \\
\hline IE3 & & & 0.854 & \\
\hline IE3 & & & 0.924 & \\
\hline
\end{tabular}

Sumber: Hasil Penelitian diolah dengan smartPLS 3.0, 2021

Berdasarkan tabel 1, menunjukkan bahwa semua variabel penelitian memiliki nilai-nilai outer loading dari setiap item pertanyaan > loading faktor 0,50, yang artinya dapat diterima atau lebih dianggap memiliki validitas yang cukup kuat untuk menjelaskan konstruk laten.

\section{b. Uji Reabilitas}

Instrument realiabilitas dalam penelitian ini diukur dengan dua Kriteria yaitu nilai composite reliability dan cronbach's alpha. Penggunaan cronbach's alpha cenderung menaksirkan lebih rendah reliabilitas variabel dibandingkan composite reliability sehingga disarankan untuk menggunakan composite reliability menurut haryono (2017). Sebuah konstruk dapat dikatakan reliable apabila nilai cronbach's alpha lebih 0,70 sedangkan menurut Ghozali (2005) variabel dikatakan reriabel jika nilai composite reliability di atas 0,70 . 
Analisis Pengaruh Financial Literacy, Asymmetry Information

Tabel 2. Construct reliability dan validity

\begin{tabular}{|l|c|c|c|c|}
\hline & $\begin{array}{c}\text { Cronbach' } \\
\text { s Alpha }\end{array}$ & $\begin{array}{c}\text { rho_ } \\
A_{-}\end{array}$ & $\begin{array}{c}\text { Composit } \\
e \\
\text { Reliabilit } \\
y\end{array}$ & $\begin{array}{c}\text { Average } \\
\text { Varianc } \\
e \\
\text { Extracte } \\
d(\text { AVE })\end{array}$ \\
\hline $\begin{array}{l}\text { Asymmetr } \\
y \\
\text { Informatio } \\
n\end{array}$ & 0.960 & 0.960 & 0.974 & 0.926 \\
\hline $\begin{array}{l}\text { Financial } \\
\text { Literacy }\end{array}$ & 0.935 & 0.938 & 0.959 & 0.886 \\
\hline $\begin{array}{l}\text { Keputusan } \\
\text { Investasi }\end{array}$ & 0.923 & 0.936 & 0.946 & 0.816 \\
\hline $\begin{array}{l}\text { Investasi } \\
\text { Etis }\end{array}$ & 0.918 & 0.918 & 0.942 & 0.803 \\
\hline
\end{tabular}

Sumber: Hasil Penelitian diolah dengan smartPLS 3.0, 2021

Berdasarkan tabel 2, menunjukan bahwa semua variabel penelitian memiliki nilai cronbach's alpha dan composite reliability di atas 0,70 . Oleh karena itu indikator yang digunakan dalam variabel penelitian ini dikatakan reliable. Sedangkan validitas mengunakan nilai average variance extracted (AVE) dengan nilai batasan diatas 0,50 pada tabel.2 terlihat bahwa semua variabel memiliki nilai AVE diatas 0,50. Hal ini dapat diartikan bahwa keseluruhan indikator dan variabel dinyatakan valid.

\section{c. Uji Korelasi Diskriminan}

Uji korelasi diskriminan dilakukan untuk melihat korelasi antara konstruk dengan konstruk lainya. Jika nilai akar kuadrad (square root of average) AVE setiap konstruk lebih besar daripada nilai korelasi antara konstruk dengan konstuk lainya dalam model maka dapat disimpulkan bahwa konstruk memiliki tingkat validitas yang baik.

Tabel 3. Nilai Discriminant Validity

\begin{tabular}{|l|c|c|c|c|}
\hline & $\begin{array}{c}\text { Asymmetr } \\
y\end{array}$ & $\begin{array}{c}\text { Financi } \\
\text { al } \\
\text { Informatio } \\
\text { Literacy }\end{array}$ & $\begin{array}{c}\text { Keputusa } \\
\mathrm{n} \\
\text { Investasi }\end{array}$ & $\begin{array}{c}\text { Investas } \\
\text { i Etis }\end{array}$ \\
\hline $\begin{array}{l}\text { Asymmetry } \\
\text { Information }\end{array}$ & 0.962 & & & \\
\hline
\end{tabular}

\begin{tabular}{|l|l|l|l|l|}
\hline Financial Literacy & 0.938 & 0.942 & & \\
\hline Keputusan Investasi & 0.877 & 0.826 & 0.904 & \\
\hline Investasi Etis & 0.881 & 0.887 & 0.915 & 0.896 \\
\hline
\end{tabular}

Sumber: Hasil penelitian diolah dengan smartPLS 3.0, 2021

Pada tabel 3 Perbandingan nilai akar AVE memperlihatkan bahwa masing-masing dari nilai tersebut lebih besar dibandingkan dengan korelasi antar variabel lainya, sehingga dapat ditarik kesimpulan bahwa semua variabel laten dalam penelitian memiliki construct validity dan discriminant validity yang baik.

\section{Pengujian Struktural Model}

Pengujian structural model dilakukan untuk melihat hubungan antara konstruk, nilai signifikansi dan $R$-square dari model penelitian. Nilai $R$-square dapat digunakan untuk menilai pengaruh variabel independen tertentu terhadap variabel dependen. Nilai estimasi $R$-square dapat dilihat pada Tabel berikut ini.

Tabel 4. Nilai $R$-square

\begin{tabular}{|c|c|c|}
\hline & $\begin{array}{c}\text { R- } \\
\text { square }\end{array}$ & $\begin{array}{c}\text { Adjusted } \boldsymbol{R} \text { - } \\
\text { square }\end{array}$ \\
\hline $\begin{array}{c}\text { Keputusan } \\
\text { Investasi }\end{array}$ & 0.827 & 0.867 \\
\hline Investasi Etis & 0.807 & 0.801 \\
\hline
\end{tabular}

Berdasarkan tabel 4 diketahui bahwa Nilai $R$-square untuk variabel kesadaran sebesar 0,827 atau $82,7 \%$ yang dapat di interprestasikan bahwa besarnya faktor yang mempengaruhi keputusan investasi dapat dijelaskan oleh faktor financial literacy dan asymmetry information sedangkan sebesar 17,3\% dipengaruhi oleh variabel lain diluar penelitian ini. Nilai $R$-square untuk variabel investasi etis sebesar 0,807 atau $80,7 \%$ yang dapat di interprestasikan bahwa besarnya faktor yang mempengaruhi investasi etis dapat dijelaskan oleh faktor financial literacy dan asymmetry information 
sedangkan sebesar 19,3\% dipengaruhi oleh variabel lain diluar penelitian ini.

\section{Uji Hipotesis}

Diterima atau tidaknya sebuah hipotesis yang diajukan, perlu dilakukan pengujian hipotesis dengan menggunakan fungsi Bootstripping pada SmartPLS 3.0. hipotesis diterima pada saat tingkat signifikan lebih kecil dari 0,05 atau t-value melebihi nilai kritisnya. Nilai $\mathrm{t}$ statistics untuk tingkat signifikansi 5\% sebesar 1,96. dapat dilihat pada gambar path diagram serta tabel Hasil Path Coefficient berkut ini:

\section{Gambar 1. Path Diagram}

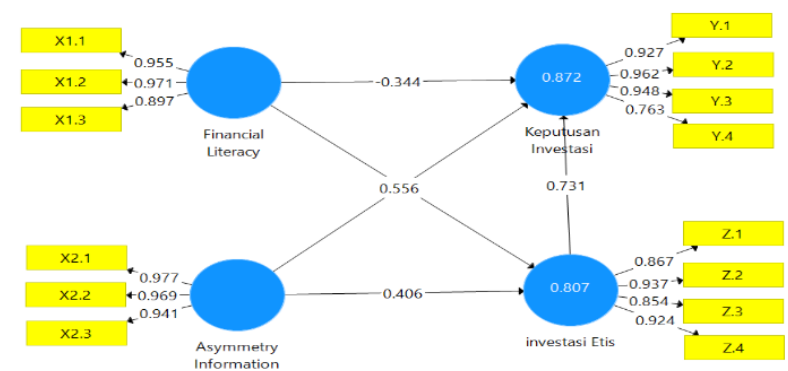

Sumber: Hasil penelitian diolah dengan smartPLS 3.0, 2021.

Tabel 5. Uji Hipotesis Hasil Path Coefficient

\begin{tabular}{|c|c|c|c|c|c|c|c|}
\hline & $\begin{array}{l}\text { Variabel/Konstr } \\
\text { uk }\end{array}$ & $\begin{array}{l}\text { Origi } \\
\text { nal } \\
\text { Sam } \\
\text { pel }\end{array}$ & $\begin{array}{l}\text { Sam } \\
\text { pel } \\
\text { Mea } \\
\text { n }\end{array}$ & $\begin{array}{c}\text { Standa } \\
\text { rd } \\
\text { Deviat } \\
\text { ion } \\
\text { (STD } \\
\text { EV) }\end{array}$ & $\begin{array}{c}\mathrm{T} \\
\text { Statis } \\
\text { tik } \\
(\mathrm{O} / \mathrm{S} \\
\mathrm{TDE} \\
\mathrm{V})\end{array}$ & $\begin{array}{c}\mathrm{P} \\
\text { Val } \\
\text { ues }\end{array}$ & Hasil \\
\hline $\begin{array}{c}\mathrm{H} \\
1\end{array}$ & $\begin{array}{l}\text { Financial } \\
\text { Literacy } \rightarrow \\
\text { Investasi Etis } \\
\end{array}$ & 0.506 & $\begin{array}{c}0.48 \\
8\end{array}$ & 0.141 & 3.584 & $\begin{array}{c}0.00 \\
0\end{array}$ & $\begin{array}{l}\text { Diter } \\
\text { ima }\end{array}$ \\
\hline $\begin{array}{l}\mathrm{H} \\
2\end{array}$ & $\begin{array}{l}\text { Asymmetry } \\
\text { Information } \rightarrow \\
\text { Investasi Etis }\end{array}$ & 0.406 & $\begin{array}{c}0.42 \\
2\end{array}$ & 0.130 & 3.133 & $\begin{array}{c}0.00 \\
2\end{array}$ & $\begin{array}{c}\text { Diter } \\
\text { ima }\end{array}$ \\
\hline $\begin{array}{l}\mathrm{H} \\
3\end{array}$ & $\begin{array}{l}\text { Financial } \\
\text { Literacy } \rightarrow \\
\text { Keputusan } \\
\text { Investasi }\end{array}$ & $\begin{array}{c}- \\
0.344\end{array}$ & $\begin{array}{c}- \\
0.38 \\
0\end{array}$ & 0.256 & 1.345 & $\begin{array}{c}0.17 \\
9\end{array}$ & $\begin{array}{c}\text { Ditol } \\
\text { ak }\end{array}$ \\
\hline $\begin{array}{l}\mathrm{H} \\
4\end{array}$ & $\begin{array}{l}\text { Asymmetry } \\
\text { Information } \rightarrow \\
\text { Keputusan } \\
\text { Investasi }\end{array}$ & 0.556 & $\begin{array}{c}0.60 \\
1\end{array}$ & 0.263 & 2.112 & $\begin{array}{c}0.03 \\
5\end{array}$ & $\begin{array}{c}\text { Diter } \\
\text { ima }\end{array}$ \\
\hline $\begin{array}{l}\mathrm{H} \\
5\end{array}$ & $\begin{array}{l}\text { Investasi Etis } \rightarrow \\
\text { Keputusan } \\
\text { Investasi }\end{array}$ & 0.731 & $\begin{array}{c}0.72 \\
1\end{array}$ & 0.156 & 4.690 & $\begin{array}{c}0.00 \\
0\end{array}$ & $\begin{array}{c}\text { Diter } \\
\text { ima }\end{array}$ \\
\hline $\begin{array}{l}\mathrm{H} \\
6\end{array}$ & $\begin{array}{l}\text { Financial } \\
\text { Literacy } \rightarrow \\
\text { Investasi Etis } \rightarrow\end{array}$ & 0.370 & $\begin{array}{c}0.34 \\
5\end{array}$ & 0.111 & 3.330 & $\begin{array}{c}0.00 \\
1\end{array}$ & $\begin{array}{c}\text { Diter } \\
\text { ima }\end{array}$ \\
\hline
\end{tabular}

\begin{tabular}{|c|l|c|c|c|c|c|c|}
\hline & Keputusan & & & & & & \\
\hline Investasi & Asymmetry & 0.297 & 0.31 & 0.131 & 2.263 & 0.02 & Diter \\
7 & $\begin{array}{l}\text { Information } \rightarrow \\
\text { Investasi Etis } \rightarrow\end{array}$ & & 0 & & & 4 & ima \\
& $\begin{array}{l}\text { Keputusan } \\
\text { Investasi }\end{array}$ & & & & & & \\
\hline
\end{tabular}

Sumber: Hasil penelitian, diolah dengan SmartPLS 3.0, 2021

Dari path coefficient di atas dapat dilihat nilai original sampel, $\mathrm{p}$ value atau $\mathrm{t}$ statistics yang digunakan sebagai acuan untuk mengambil keputusan hipotesis diterima atau hipotesis ditolak. Hipotesis dapat diterima jika nilai $\mathrm{t}$ statistics $>\mathrm{t}$ tabel atau $\mathrm{p}$ value $<0,05$.

\section{Pembahasan}

Dasar pemikiran dari penelitian ini adalah untuk memindai dan mengamati faktor-faktor determinan dari keputusan investasi investor pasar modal di kota Palembang yang terdiri dari financial literacy, asymmetry information dan investasi etis.

\section{H1: Financial literacy berpengaruh terhadap investasi etis}

Dari hasil penelitian hipotesis pertama terhadap pengaruh antara financial literacy terhadap investasi etis. Hal ini sesuai dengan hasil path coefficients dengan nilai t-statistik financial literacy terhadap investasi etis $3.584<1.96$ atau dapat dilihat $\mathrm{p}$ value nya yang bernilai $0.000>0.05$, dengan nilai original sampel adalah positif sebesar 0.506 yang menunjukan bahwa arah hubungan antara financial literacy terhadap investasi etis adalah positif.

Hasil penelitian ini sesuai dengan penelitian sebelumnya oleh Emil Hasudungan dkk. dimana dibuktikan dengan hasil uji statistik financial berpengaruh terhadap investasi etis. Setiap individu dapat membuat keputusan dan efektif dengan sumber daya keuangan mereka dengan pengetahuan, keyakinan dan keterampilan dalam pengelolaan keuangan seperti membuat 
perencanaan keuangan, akumulasi keuangan, pensiun dan hutang, semakin tinggi pemahaman individu terkait dengan financial literacy membuat individu memahami dan menerapkan etika investasi yang berlaku dan sesuai dengan normanorma invetasi islam di pasar moadal syariah.

\section{H2: Asymmetry information terhadap investasi etis}

Dari hasil penelitian hipotesis kedua terdapat pengaruh positif antara asymmetry infomatrion terhadap investasi etis. Hal ini sesuai dengan path coefficient dengan nilai t-statistik sebesar $3.113>$ 1.96 atau dapat juga dilihat pada nilai $\mathrm{p}$ value yang bernilai $0.002<0.05$ dan nilai original sampel sebesar 0.406 yang menunjukan arah hubungan antara asymmetry information dan investasi etis adalah positif.

Hasil penelitian ini sesuai dengan hasil penelitian Miftahul Izza (2018) dimana dibuktikan dengan hasil uji t statistik sebesar $2.041>1.96$ atau dapat juga dilihat pada $\mathrm{p}$ value $0.047<0.05$ yang menunjukan bahwa asymmetry information berpengaruh positif dan signifikan terhadap investasi etis.

\section{H3: Financial literacy berpengaruh terhadap keputusan investasi}

Dari hasil penelitian ini tidak terdapat pengaruh antara financial literacy terhadap keputusan investasi. Hal ini sesuai dengan hasil path coefficients dengan nilai t-statistik religiusitas terhadap minat berwakaf uang sebesar $1.345<1.96$ atau dapat juga dilihat pada nilai $\mathrm{p}$ value yang bernilai $0.179>0.05$ dan nilai original sampel sebesar -0.344 yang menunjukan arah hubungan antara financial literacy terhadap keputusan investasi adalah negatif.
Hasil penelitian ini sejalan dengan penelitian Rafinza Widiar Pradhana (2018), dalam penelitianya menjelaskan tidak terdapat hubungan antara financial literacy terhadap keputusan investasi. Dalam hal ini diindikasi bahwa financial literacy tidak menjadi acuan langsung bagi investor dalam mengambil keputusan investasi di pasar modal.

\section{H4: Asymmetry information berpengaruh terhadap keputusan investasi}

Hasil penelitian terhadap pengaruh asymmetry information terhadap keputusan investasi, dalam penelitian ini menemukan bahwa asymmetry information berpengaruh positif dan signifikan terhadap keputusan investasi, hal ini sesuai dengan hasil path coefficients dengan nilai tstatistik asymmetry information terhadap keputusan investasi $2.112>1.96$ atau dapat dilihat $\mathrm{p}$ value nya yang bernilai $0.000<0.05$ dan nilai original sampel adalah positif sebesar 0.556 yang menunjukan arah hubungan antara asymmetry information terhadap keputusan investasi.

Penelitian ini sesuai dengan penelitian sebelumnya oleh Taufan Darmawan, Nurwahidin dan Saiful Anwar (2020) yang menjelaskan bahwa asymmetry information memberikan pengaruh positif dan signifikan terhadap keputusan investasi. Penelitian ini menjelaskan bahwa asymmetery information efektif dan relevan dalam mengambil keputusan investasi.

\section{H5: Investasi etis berpengaruh terhadap keputusan investasi}

Dari hasil penelitian terhadap pengaruh investasi etis terhadap keputusan investasi. Nilai tstatistik investasi etis sebesar $4.690>1.96$ atau dapat dilihat $\mathrm{p}$ value yang bernilai $0.000<0.05$. nilai original sampel adalah positif sebesar 0.731 
yang menunjukan arah hubungan antara investasi etis terhadap keputusan investasi adalah positif.

Hasil penelitian ini sesuai dengan penelitian sebelumnya oleh Emil Hasudungan Sihotang, Muhammad Adam dan Yuliani (2020) yang menunjukan bahwa investasi etis menjadi salah satu variabel yang berpengaruh secara positif terhadap keputusan investasi.

\section{H6: Financial literacy berpengaruh terhadap keputusan investasi melalui investasi etis}

Dari hasil penelitian ini pengaruh financial literacy terhadap keputusan investasi melalui investasi etis menemukan bahwa financial literacy berpengaruh positif dan signifikan terhadap keputusan investasi, hal ini sesuai dengan nilai tstatistik sebesar $3.330>1.96$ atau dapat dilihat $p$ value yang bernilai $0.001<0.05$ dan nilai original sampel positif 0.370 .

Hasil penelitian ini sesuai dengan penelitian sebelumnya oleh Emil Hasudungan Sihotang, Muhammad Adam dan Yuliani (2020) bahwa financial berpengaruh secara positif dan signifikan terhadap keputusan investasi melalui investasi etis bagi investor pasar modal di kota Palembang.

\section{H7: Asymmetry information berpengaruh terhadap keputusan investasi melalui investasi etis}

Dari hasil penelitian ini ditemukan pengaruh asymmetry information berpengaruh terhadap keputusan investasi melalui investasi etis yang ditunjukan dengan nilai t-statistik kesadaran sebesar $2.263>1.96$ atau dapat dilihat $p$ value yang bernilai $0.001<0.05$. nilai original sampel adalah positif sebesar 0.297 yang menunjukan arah asymmetry information terhadap keputusan investasi melalui investasi etis adalah positif.
Hal ini sesuai dengan teori minat yaitu dengan motif sosial dapat membangkitkan kesadaran untuk melakukan aktivitas tertentu. Hal ini ditujukan dengan semakin giat strategi penggalangan dilakukan maka semakin besar keingintahuan dan kesadaran masyarakat akan pentingnya membangun ekonomi Islam dan membangkitkan minat masyarakat untuk berwakaf uang.

\section{Kesimpulan}

Penelitian ini menyimpulkan bahwa pertama, financial literacy berpengaruh terhadap investasi etis investor di kota Palembang. Kedua, asymmetry information berpengaruh terhadap investasi etis investor di kota Palembang. Ketiga, financial literacy tidak berpengaruh terhadap keputusan investasi investor di kota Palembang. Keempat, asymmetry information berpengaruh terhadap keputusan investasi investor di kota Palembang. Kelima, investasi etis berpengaruh terhadap keputusan investasi. Keenam, financial literacy berpengaruh terhadap keputusan investasi investor di kota Palembang melalui investasi etis. Dan ketujuh, asymmetry information berpengaruh terhadap keputusan investasi investor di kota Palembang melalui investasi etis.

\section{Daftar Pustaka}

Al-Tamimi, H. A. H., Kalli. A. A. B. (2009). Financial Literacy and Investment Decisions Of UAE Investors. Emerald Group Publishing Limited the Journal of Risk Finance, Vol. 10 No. 5, 2009 pp. DOI 10.1108/15265940911001402. UAE.

Burhanudin Susanto, Aspek Hukum Lembaga Keungan Syariah, Yogyakarta: Graha Ilmu, 2010.

Cole. S, and N. Fernando. 2008. Assessing the importance of financial literacy. Asian 
Development Bank: Finance for the poor. Oxford University.Volum 9 No 3.

Departemen Pendidikan, Kamus Besar Bahasa Indonesia, (Jakarta: Balai Pustaka,2005).

Depdiknas, Kamus Besar Bahasa Indonesia ,(Jakarta: Balai Pustaka, 2002).

Esta Lestari, "Perbandingan Kinerja Pasar Modal Syari'ah dan Konvensional di Indonesia: Pendekatan Volatilitas, "dalam Jusmaliani (ed.), Investasi Syari'ah (Yogyakarta: Kreasi Wacana, 2008).

Fatwa Majelis Ulama Indonesia, Keputusan Fatwa Majelis Ulama Indonesia Tentang Penerapan Prinsip Syariah Terhadap Mekanisme perdagangan Efek di Pasar Reguler Bursa Efek Indonesia, ditetapkan di Jakarta, pada tanggal 08 Maret 2011.

Hair, et al.(1998). Multivariate Data Analysis, Fifth Edition, Prentice Hall, Upper Saddle. River : New Jersey.

Hunjra, A, I. and Rehman, Z.(2016). Factors affecting investment decision mediated by risk aversion: A case of Pakistani investors. International Journal of Economics and Empirical Research. 4(4), 169- 181.

Husain Syahatah dan Siddiq Muh. Al-Amin AdhDhahir, Transaksi dan Etika Bisnis Islam, Terj. Saptono Budi Satryo dan Fauziah R, (Jakarta : Visi Insani Publishing, 2005), hlm. 22.

Husnan, Suad dan Enny Pudjiastuti, "Dasar-dasar Manajemen Keuangan", Edisi Kelima (Jakarta: UPP STIM YKPN, 2006), hlm.181.

Junaedi, D 2005, 'Dampak Tingkat Pengungkapan Informasi Perusahaan terhadap Volume Perdagangan dan Return Saham', Jurnal Akuntansi dan Keuangan Indonesia, vol.2, no.2, pp. 14-20.

Juruveciene, D., Ivanova, O. (2013). Behaviour finance: theory and survey. Science Future of Lithuania. 5: 53-58.
Kahneman dan Tvesky. A (1979), Prospect theory: An analysis of decision under risk, Journal of The Economics Society 47(2), 263-291.

Khaerul Umam, Pasar Modal Syariah \& Praktir Pasar Modal Syariah, Bandung: Pustaka Setia, 2013.

Khairunizam dan Isbanah, Y, Pengaruh Financial Literacy dan Behavioural Finance Factors terhadap keputusan investasi, Jurnal: Ilmu Manajemen Volume 7 No.2 2019, hlm.516.

Kirana, Dewi Windisukma, 2015 "pengaruh kesadaran halal terhadap sikap dan implikasinya terhadap minat beli ulang", Universitas Diponegoro.

Kuncoro, M 2009, 'Metode Riset Untuk Bisnis dan Ekonomi', Erlangga, Jakarta, Indonesia.

La Rahmad Hidayat, Djoko Setiadi, dan Musdalifah Azis, Pengaruh Inflasi dan Suku Bunga dan Niai Tukar Rupiah serta Jumlah Uang Beredar terhadap Return Saham, Jurnal: Forum Ekonomi 19 No.2, 10 Januari 2018, hlm.149.

Levi, S \& Zhang, XJ 2008, 'Information Asymmetry and the Increase in Expected Stock Returns Before Earnings Announcements', Review of Quantitative Finance and Accounting, vol. 11, no2 , pp 165-182.

Lundholm, RJ \& Myers, L 2002, 'Bringing the Future Forward: The Effect of Disclosure on The Returns Earnings Relation', Journal of Accounting Research, vol. 40, no. 02, pp. 809-839.

Manurung, AH, 2013, 'Teori Investasi : Konsep dan Empiris', PT. Adler Manurung Press, Jakarta, Indonesia.

Merton, RC 1987, 'A Simple Model of Capital Market Equilibrium with Incomplete Information', Journal of Finance, vol. 42, no. 02, pp. 483-510.

Muhammad Chaidir, e.t. al, Etika Investasi Syariah, Jurnal: Qus-Qazah Vol.1, No.1 Desember 2019, hlm.7. 
Muhammad Zaenudin, Isu, Problematika, dan Dinamika Perekonomian dan Kebijakan Publik, Jakarta: Deepublish 2018.

Ni Made dan Arya Pribadi, Pengaruh Set Kesempatan Investasi Terhadap Hubungan Antara Asimetri Informasi Dan Tingkat Manajemen Laba Pada Perusahaan Manufaktur Yang Terdaftar Di Bursa Efek Indonesia (BEI), Jurnal: Akuntansi Bisnis Vol.6 No.2, hlm.89.

Nurul Huda dkk, Ekonomi Pembangunan Islam, Jakarta: Kencana, 2015,

Rafinza Widiar Pradhana, Pengaruh Financial Literacy, Congnitive Bias dan Emotional Blas terhadap Keputusan Investasi, Jurnal Ilmu Manajemen V.6 Nomor.3, 2018, hlm. 110.

Rahmawati, SY \& Qomariyah, N , 'Pengaruh Asimetri Informasi Terhadap Praktik Manajemen Laba pada Perusahaan Perbankan Publik yang Terdaftar di Bursa Efek Jakarta', Simposium Nasional Akuntansi 9, Universitas Andalas, Padang, 14-16 April 2006.

Sumsel.news.id, Hari Mulyono Kepala BEI Perwakilan Sumatera Selatan, 2020. 06 Maret 2021.

Tandelilin, Eduardus, "Portofolio Dan Investasi Teori dan Aplikasi", Edisi Pertama (Yoyakarta: Kanisius, 2010).

Taufan Darmawan dkk, Analisis Faktor yang Memengaruhi Keputusan Investasi di Pasar Modal Syariah, Jurnal: Middle East and Islamic Studies, Volume 6, No.2 JuliDesember 2019, hlm.193.

Van Horne, James C dan John M. Wachowicz, "Prinsip-prinsip Manajemen Keuangan", Buku Pertama, Edisi Keduabelas, (Jakarta: Salemba Empat, 20050, hlm. 3.

www.bps.go.id

www.ojk.go.id/regulasi/undang -undang, diakses 27 Mei 2021

Zulfikar, Pengantar Pasar Modal Dengan Pendekatan Statistika, Yogyakarta:
Deepublish, 2016, hlm.4 dalam Iskandar Budiman, "Mengenal Lebih Dekat Ananlisis Pasar Modal Perspektif Syari'ah", Jurnal: Investasi Syariah 1, No.01, July 2017, Hlm.33. 